\title{
Length-weight relationship and relative condition factor of Liza subviridis (Valenciennes, 1836) in Pinang River Estuary, Balik Pulau, Penang, Malaysia
}

\author{
N. ZOLKHIFLEE, K. M. ZAIN, M. Y. HOSSAIN*AND K. YAHYA \\ School of Biological Sciences, Universiti Sains Malaysia, 11800 Penang, Malaysia \\ ${ }^{*}$ University of Rajshahi, Faculty of Agriculture, Department of Fisheries, Rajshahi - 6205, Bangladesh \\ e-mail:khairun@usm.my
}

\section{ABSTRACT}

Length-weight relationship and relative condition factor $(K n)$ of greenback mullet Liza subviridis (Valenciennes, 1836) were estimated from 2286 samples (635 males and 1651 females) collected from the Pinang River Estuary, Balik Pulau, Penang from March 2013 to February 2014. The length-weight relationship and growth pattern were: $\mathrm{W}=0.0117 \mathrm{~L}^{2.9989}$ (isometric) for pooled samples (male and female together), $\mathrm{W}=0.0157 \mathrm{~L}^{2.8787}$ (negative allometric) for males and $\mathrm{W}=0.0109 \mathrm{~L}^{3.0284}$ (isometric) for females. Independent t-test showed that female $b$ value was higher than that of the males $(\mathrm{p}<0.05)$ with no significant difference between the wet and dry seasons (independent $\mathrm{t}$-test, $\mathrm{p}>0.05$ ). The mean $K n$ of $L$. subviridis was $1.01 \pm 0.13$; however, no significant difference was detected between wet and dry seasons and between male and female samples (independent t-test, $\mathrm{p}>0.05$ ).

Keywords: Length-weight relationship, Liza subviridis, Relative condition factor, Wet and dry season

Length-weight relationship and coefficient of condition provide useful information for understanding the biology and ecology of fish in terms of estimating the average weight corresponding to a known length group (Froese, 2006) and in evaluating the relative well-being of a fish population (Bolger and Connolly, 1989). This in turn would provide inputs for development of stock assessment models for sustainable management of fish in an aquatic ecosystem (Mendes et al., 2004). The lengthweight relationship of fishes belonging to the family Mugilidae have been extensively studied worldwide (Moorthy et al., 2003; Lawson and Jimoh, 2010; Dankwa, 2011; Renjini and Nandan, 2011; Gondal et al.,2014).

The present study was undertaken to establish the length-weight relationship and relative condition factor of Liza subviridis (Valenciennes, 1836) in a small estuarine area of Pinang River Estuary, Balik Pulau, Penang, Malaysia, which is subjected to various anthropogenic activities. A few researchers have studied the same species in the Merbok Estuary of Kedah (Nor Aziella, 2012) and in the Vellar Estuary of India (Rahman et al., 2013). However, these studies were conducted in large estuarine systems with less anthropogenic effect compared to the Pinang River Estuary considered in this study. A total of 2286 samples of L. subviridis were collected from March 2013 to February 2014 using gill net and cast net. The study site experienced wet season from June to November 2013 and dry season from March to May 2013 and December 2013 to February 2014 (Malaysian
Meteorology Department, 2013; 2014). L. subviridis was identified from the morphometric and meristic features as per Harrison and Senou (1999) and Nor Aziella (2012). The total length of the fishes sampled were measured to the nearest $0.1 \mathrm{~cm}$ using measuring board and weighed to the nearest $1 \mathrm{~g}$ using a portable scale (OHAUS model LS2000). The shape of the anus was used to differentiate the sex, which was further confirmed by examining the gonads after dissecting the abdomen.

The length-weight relationship was calculated as $W=a L^{b}$ (Froese, 2006), where $W$ is total weight (g), $L$ is total length $(\mathrm{cm})$ (from the tip of the snout to the tip of caudal fin), $a$ is constant proportionality (intercept value) and $b$ is allometry coefficient (slope). The allometric equation was then changed to the linear form as: $\ln \mathrm{W}=\ln a+b \ln \mathrm{L}$. The equation is the same as the linear equation $\mathrm{Y}=\mathrm{c}+\mathrm{mX}$, where $\ln \mathrm{W}$ and $\ln \mathrm{L}$ equals $\mathrm{Y}$ and $\mathrm{X}$ and $\ln a$ and $b$ represent the intercept and slope of the graph.

The following equation from Pauly (1984) was used to test whether the value of $b$ calculated was significantly different from the cubic law (3):

$$
\hat{t}=\frac{s d \ln L}{s d \ln W} \cdot \frac{|b-3|}{\sqrt{1-r^{2}}} \cdot \sqrt{n-2}
$$

where, sd $\ln \mathrm{L}$ and sd $\ln \mathrm{W}$ are the standard deviations of the $\ln$ length and weight. The value of $b$ is significantly different from the cubic law if the $t$ calculated is greater than the $\mathrm{t}$ distribution table value for $\mathrm{n}-2$ degrees of freedom. 
The confidence limit of population of $L$. subviridis was calculated based on formula by Zar (2010):

$$
\mathrm{b} \pm(\mathrm{t} 1-\alpha / 2, \mathrm{n}-2) \cdot \sqrt{ }\left[\mathrm{S}^{2} /(\mathrm{n}-2)(\mathrm{SD} T L)\right]
$$

where $b$ is the slope calculated from the length-weight relationship, $S^{2}$ is the mean square error and SD TL is the standard deviation of total length.

The relative condition factor $(K n)$ was calculated using the following formula, $\mathrm{Kn}=\mathrm{W} / \mathrm{W}$ ' (Le Cren, 1951), as cited by Froese (2006), where W is the total weight (g); $\mathrm{W}^{\prime}$ is $a \mathrm{~L}^{b}$, where $a$ and $b$ are the intercept and slope obtained from length-weight equation.

Independent samples t-test was computed for comparing all the dependent variables ( $b$ value and $K n$ of fish) calculated with seasonal factors of the dry and wet season and the gender factors (male and female). Statistical analyses were performed using SPSS software v20.

The length-weight relationship analysis showed that the $b$ values for all individuals, males and females were $2.999 \pm 0.005,2.879 \pm 0.004$ and $3.028 \pm 0.005$ respectively. The calculated $b$ value was within the suggested range of Froese (2006), i.e., in the range of $2.5>b<3.5$. The mean $b$ value of the females was higher than that of the males (t-test, $\mathrm{p}<0.05)$. A higher $b$ value in the females was also observed by Rahman et al. (2013). Oren (1981) indicated that during spawning, the sex ratio of 1 female to 4 males was spotted for striped mullets, where the female was much larger than the males. The higher $b$ value observed in females was due to the weight of the ripe ovary that has affected the length-weight relationship (Hossain, 2010).

Statistical analysis showed that there was no significant difference detected for the $b$ values of all samples and females from the cubic law $b=3(\mathrm{p}>0.05)$, suggesting that the fish experienced isometric growth. The $b$ value of the males was significantly different from the cubic law (3), indicating that the fish experienced negative allometric growth. A similar growth pattern was observed by Rahman et al. (2013) for L. subviridis in Parangipettai waters of India, but a different result was observed by Nor Aziella (2012) in Merbok Estuary of Kedah (negative allometric for males, females and combined sex). Merbok Estuary in comparison to the Pinang River (which is shallow and a small microtidal estuary) is a large macrotidal system with high productivity (Khairun, 2004) as well as high predatory density. Long periods of exposure towards high predatory density would have altered the behavioural patterns (e. g. decrease in feeding activity) leading to poor physiological condition (Laakkonen, 2006). This situation would certainly affect the growth pattern of the fish population inhabiting the area.

It was observed that the $b$ values for the wet season were relatively higher compared to that of the dry season, but this difference was not statistically significant (Table 1). The difference in $b$ values for fish population does not depend on a single factor, e.g. seasonal variations. Instead, it is a combination of various factors (Froese, 2006). The difference in the $b$ value could be the combination of i) condition of the fish sample, e.g. stages of gonad development (Froese, 2006); ii) sampling procedure, e.g. number of samples and length ranges of the samples collected (Hossain, 2010); and iii) environmental characteristic of the habitat, e.g. productivity condition of the water (Jyrwa, 2015).

A higher $K n$ value was observed in the females compared to the males. This result is in agreement with previous studies by Wijeyaratne and Costa (1987) on $L$. subviridis and by Das (1977) on Mugil cephalus. Das (1977) and Oren (1981) reported that the higher condition of females than males could be attributed to the heavier weight of the ovaries in females compared to the testes in males.

There was no significant difference in $K n$ values between dry and wet seasons. Generally, the seasonal variation in the coefficient of condition of a fish species is attributed to the food availability and ripening of gonads during the pre-spawning period (usually during the onset of wet season) (Froese, 2006). However, a different situation was observed in Pinang River Estuary as there were no obvious differences between the wet and dry seasons in terms of environmental parameters measured (Nurul Ruhayu, 2010) and hence there might not be

Table 1. $b$ values of $L$. subviridis between wet and dry seasons within the twelve months sampling.

\begin{tabular}{|c|c|c|c|c|c|}
\hline Season & Months & $b( \pm 95 \% \mathrm{CL})$ & Season & Months & $b( \pm 95 \% \mathrm{CL})$ \\
\hline \multirow[t]{6}{*}{ Wet } & Jun-13 & $2.950 \pm 0.005$ & Dry & Dec-13 & $2.644 \pm 0.004 *$ \\
\hline & Jul-13 & $2.872 \pm 0.004$ & & Jan-14 & $2.589 \pm 0.005^{*}$ \\
\hline & Aug-13 & $2.980 \pm 0.005$ & & Feb-14 & $2.763 \pm 0.005^{*}$ \\
\hline & Sept-13 & $2.856 \pm 0.002$ & & Mac-13 & $2.856 \pm 0.003$ \\
\hline & Oct-13 & $2.831 \pm 0.003$ & & Apr-13 & $2.617 \pm 0.004^{*}$ \\
\hline & Nov-13 & $2.848 \pm 0.003$ & & May-13 & $2.707 \pm 0.003^{*}$ \\
\hline
\end{tabular}

"Indicates significant difference from cubic law (3) at $\mathrm{p}<0.05 ; b$ (slope) with $\pm 95 \%$ confident limit (CL); SD - standard deviation. 
much difference in the condition and the amount of food available during both seasons.

Intra and inter-species difference was reported in the coefficient of condition due to the individual biology of the fish viz., gonad maturation process in male and female, body size, accumulation of lipid and muscle growth (Barnharm and Baxte, 1998), environmental conditions of the habitat such as different salinity regime (Nehemia et al., 2012) and different length class that had been sampled during the study period (Mbaru et al., 2011; Shukor et al., 2008).

Pinang River estuarine area is still conducive to support the growing population of $L$. subviridis inhabiting the area. But the authorities have to bear in mind that the decline of fish diversity in this area (especially the predatory species) due to high impact of anthropogenic activities in the surrounding area will eventually lead to the decline of this species as well. Results of the present study will help to initiate awareness on the importance of improving and maintaining the condition of an estuarine area in order to maintain good well-being of fish population inhabiting the aquatic ecosystem.

\section{Acknowledgements}

Grateful appreciation is extended to the Ministry of Education, Malaysia for the Exploratory Research Grant Scheme 203/PBIOLOGI/ 6730136.

\section{References}

Barnham, C. and Baxter, A. 1998. Condition factor, K, for Salmonid fish. Fisheries Notes, Department of Primary Industries, State of Victoria, Australia, p. 1-3.

Bolger, T. and Connolly, P. L.1989. The selection of suitable indices for the measurement and analysis of fish condition. J. Fish Biol., 34: 171-182.

Dankwa, R. H. 2011. Length-weight relationship and growth parameters of grey mullets (Pisces: Mugilidae) in two estuaries in Ghana. West African J. Appl. Ecol., 18: 53-61.

Das, H. D. 1977. Length-weight relationship and relative condition of grey mullet, Mugil cephalus L. Mahasagar., 10(3\&4): 145-149.

Froese, R. 2006. Cube law, condition factor and weight-length relationship: History, meta-analysis and recommendations. J. Appl. Ichthyol., 22: 241-253.

Gondal. M. A., Qureshi. N. A. and Saher, N. U. 2014. Morphometric studies on subadult Liza subviridis and Sillago sihama from Sonmiani Bay (Miani Hor), Balochistan, Pakistan. J. Biores. Manag., 1(1): 1-7.

Harrison, I. J. and Senou, H. 1999. Order Mugiliformes. In: Carpenter, K. E. and Niem, V. H. (Eds.), The living marine resources of the Western Central Pacific, FAO species identification guide for fisheries purposes. FAO, Rome, p. 2069-2790.
Hossain, Md. Y. 2010. Morphometric relationships of length-weight and length-length of four cyprinid small indigenous fish species from the Padma River (NW Bangladesh). Turk. J. Fish. Aquat. Sci., 10: 131-134.

Jyrwa, L., Bhuyan, R. N. and Nath, R. 2015. Length-weight relationship and condition factor of Neolissochilus hexagonolepis (MxClelland) in Meghalaya, India: A comparative study. Int. J. Fish. Aquat. Stud., 3(1): 419-422.

Khairun, Y. 2004. Autotrofi dan heterotrofi komuniti plankton di muara paya bakau tropika. Ph. D. thesis. Universiti Sains Malaysia, Penang, Malaysia.

Laakkonen, M. V. M. 2006. The effects of long-term predator exposure on body composition and condition of young Artic charr (Salvelinus alpinus). Ann. Zool. Fennici., 43: $263-270$

Lawson, E. O. and Jimoh, A. A. 2010. Aspects of the biology of grey mullet, Mugil cephalus, in Lagos lagoon, Nigeria. AACL Bioflux., 3(3): 181-194.

Le Cren, E. D. 1951. The length-weight relationship and seasonal cycle in: Gonad weight and condition in the perch, Perca fluviatillis. J. Anim. Ecol., 20: 201-219.

Malaysian Meteorological Department 2013 and 2014. Records on daily rainfall amount, Bayan Lepas Station, March 2013-February 2014. http://www.met.gov.my/en/web/ metmalaysia/observations/surface/dailyrainfal

Mbaru, E. M., Kimani, E. N., Otwoma, L. M., Kimeli, A. and Mkare, T. K. 2011. Abundance, length-weight relationship and condition factor in selected reef fishes of the Kenyan marine artisanal fishery. Adv. J. Food Sci. Technol., 3(1): 1-8.

Mendes, B., Fonseca, P. and Campos, A. 2004. Weight-length relationship for 46 fish species of the Portuguese west coast. J. Appl. Ichthyol., 20: 355-367.

Moorthy, K. S. V., Reddy, H. R. V. and Annappaswamy, T. S. 2003. Age and growth of blue spot mullet, Valamugil seheli (Forskal) from Mangalore. Indian J. Fish., 50(1): 73-79.

Nehemia, A., Maganira, J. D. and Rumisha, C. 2012. Length-weight relationship and condition factor of tilapia species grown in marine and freshwater ponds. Agric. Biol. J. N. Am., 3(3): 117-124.

Nor Aziella, M. R. 2012. Population biology of the greenback grey mullet, Chelon subviridis (Valenciennes, 1836) in Merbok Estuary, Kedah. M. Sc. thesis, University Sains Malaysia, Penang Malaysia.

Nurul Ruhayu, M. R. 2010. Impak aktiviti antropogen di Sungai Pinang, Balik Pulau, Pulau Pinang. M. Sc. thesis. Universiti Sains Malaysia, Penang Malaysia.

Oren, O. H. 1981. Aquaculture of grey mullets. Cambridge University Press, New York, 507 pp.

Pauly, D. 1984. Fish population dynamics in tropical waters: a manual for use for programmable calculators. ICLARM Studies and Reviews 8, Manila, 325 pp. 
Rahman, M. A. U., Khan, S. A., Lyla, P. S., Kadharsha, K., Chander, P. M. and John, B. A. 2013. Length-weight relationship and condition factor of Liza subviridis (Valenciennes, 1836). Pak. J. Biol. Sci., 16(7): 345-350.

Renjini, P. K. and Nandan, S. B. (2011). Length-weight relationship, condition factor and morphometry of gold spot mullet Liza parsia (Hamilton, 1822) from Cochin Estuary, India. J. Geo-Mar. Sci., 40(4): 567-571.

Shukor, M. N., Samat, A., Ahmad, A. K. and Ruziaton, J. 2008. Comparative analysis of length-weight relationship of
Rasbora sumatrana in relation to the physicochemical characteristics in different geographical areas in Peninsular Malaysia. Malays. Appl. Biol., 37(1): 21-29.

Wijeyaratne, M. J. S. and Costa, H. H. 1987. The biology of grey mullets in a tropical lagoon in Sri Langka. I-Age and growth. Mahasagar, 20(3): 163-170.

Zar, J. H. 2010. Biostatistical analysis, $5^{\text {th }}$ edn. Prentice Hall, Englewood, 944 pp.

Date of Receipt ～: 15.06.2016

Date of Acceptance : $\quad 02.06 .2017$ 